\title{
REGIME ADUANEIRO ESPECIAL DE DRAWBACK COMO REDUTOR DE CUSTOS NO SETOR DE FRUTICULTURA ${ }^{1}$
}

\section{DRAWBACK SPECIAL CUSTOMS ARRANGEMENTS AS REDUCER OF COSTS IN THE FRUIT INDUSTRY}

\section{RÉGIMEN ADUANERO ESPECIAL DE DRAWBACK COMO REDUCTOR DE COSTES EN EL SECTOR DE FRUTICULTURA}

Ana Heloisa Peixoto Almeida, Graduada em Ciências Contábeis. Universidade do Estado do Rio Grande do Norte, Av. Prof. Antônio Campos - Pres. Costa e Silva, Mossoró - RN, 59610210. Telefone: (84) 3315 -2202. URL da Homepage:

http://facem.uern.br/dcc/default.asp?item=depto-contabeis-apresentacao. E-mail: anahelo3@msn.com

Raniela Freitas Sampaio, Mestra em Administração pela Universidade Potiguar (PPGA/UnP). Endereço profissional: Faculdade Católica do Rio Grande do Norte, Praça Dom João Costa, 511, Santo Antônio, CEP: 59611 - 120 - Mossoró/RN, (84) 3318-7648. URL da

Homepage: http://catolicadorn.com.br/. E-mail: raniela.ricarte@gmail.com

Wênyka Preston Leite Batista da Costa, Doutoranda em Administração pela Universidade

Potiguar (PPGA/UnP). Endereço profissional: Universidade do Estado do Rio Grande do

Norte, Av. Prof. Antônio Campos - Pres. Costa e Silva, Mossoró - RN, 59610-210. Telefone:

(84) 3315 -2202. URL da Homepage: http://facem.uern.br/dcc/default.asp?item=deptocontabeis-apresentacao. E-mail: wenykapreston@hotmail.com

Luiz Antonio Felix Júnior, Doutorando em Administração pela Universidade Potiguar (PPGA/UnP). Endereço profissional: Instituto Federal de Alagoas - Av. Benedito Bentes, 1172-1198 - Benedito Bentes, Maceió - AL, 57.084-649. Telefone: (82) 2126 - 6230. URL da Homepage: https://www2.ifal.edu.br/campus/site/campus_benedito. E-mail:

luiz.felix@ifal.edu.br

Jandeson Dantas da Silva, Doutorando em Administração pela Universidade Potiguar (PPGA/UnP). Endereço profissional: Universidade do Estado do Rio Grande do Norte, Av. Prof. Antônio Campos - Pres. Costa e Silva, Mossoró - RN, 59610-210. Telefone: (84) 3315 -

2202. URL da Homepage: http://facem.uern.br/dcc/default.asp?item=depto-contabeisapresentacao. E-mail: jandeson.dantas@gmail.com

\section{RESUMO}

Como a prática do comércio exterior vem se fortalecendo ao passar dos anos, já que a mesma se tornou de fundamental relevância para o crescimento econômico dos países, torna-se necessário que as empresas tenham conhecimento e estejam preparadas para competir com os diversos tipos de mercado no âmbito internacional. Nos processos de importação não é

1 Artigo submetido em 05/09/2017, revisado em 02/01/2019, aceito em 04/03/2019 e divulgado em 20/10/2019 pelo Editor Alexandre Rabêlo Neto, após double blind review.

GєCont, v.6, n. 1, Floriano-PI, Jan-Jun. 2019. 
diferente, uma vez que a alta carga tributária brasileira impede que esse processo seja praticável sem que haja algum incentivo que possa minimizar os custos. Dessa maneira, o drawback é um incentivo aduaneiro especial de incentivo às exportações, utilizado pelas empresas para quebrar barreiras que impedem que esse tipo de comércio seja de completo sucesso. Diante disso, o objetivo geral desse trabalho foi analisar o efeito do regime aduaneiro especial de drawback como redutor de custos no setor de fruticultura. A metodologia utilizada baseou-se em pesquisa de campo, descritiva e qualitativa, o instrumento de pesquisa foi caracterizado por uma entrevista com roteiro pré-estabelecido, direcionado a uma empresa de fruticultura irrigada na cidade de Mossoró/RN. Através da análise dos dados, verificou-se que existe uma diversidade de incentivos fiscais e regimes aduaneiros abrangendo empresas que favorecem ainda mais a competitividade do empresariado junto ao mercado externo. Percebeu-se também que sem os incentivos fiscais e sem o drawback a importação de insumos seriam praticamente inviáveis, devido à alta carga tributária brasileira.

Palavras-chave: Comércio exterior. Importações. Drawback.

\section{ABSTRACT}

As the practice of foreign trade has strengthened over the years, since it has become of fundamental importance for the economic growth of the countries, it becomes necessary that the companies have knowledge and are prepared to compete with the different market types internationally. In import processes it is no different, since the high Brazilian tax burden prevents this process from being feasible without there being any incentive that can minimize costs. In this way, drawback is a special customs incentive incentive for exports, used by companies to break down barriers that prevent this type of trade from being successful. Therefore, the general objective of this work was to analyze the effect of the special drawback customs regime as a cost reducer in the fruit growing sector. The methodology used was based on field research, descriptive and qualitative, the research instrument was characterized by an interview with a pre-established itinerary, directed to an irrigated fruit company in the city of Mossoró / RN. Through the analysis of the data, it was verified that there is a diversity of fiscal incentives and customs regimes covering companies that further favor the competitiveness of business with the external market. It was also noticed that without the fiscal incentives and without the drawback the importation of inputs would be practically unviable, due to the high Brazilian tax burden.

Keywords: Foreign trade; Imports; Drawback.

\section{RESUMEN}

Como la práctica del comercio exterior se viene fortaleciendo al pasar de los años, ya que la misma se ha vuelto de fundamental relevancia para el crecimiento económico de los países, es necesario que las empresas tengan conocimiento y estén preparadas para competir con los diversos tipos de mercado en el ámbito internacional. En los procesos de importación no es diferente, ya que la alta carga tributaria brasileña impide que ese proceso sea factible sin que haya algún incentivo que pueda minimizar los costos. De esta manera, el drawback es un incentivo aduanero especial de incentivo a las exportaciones, utilizado por las empresas para romper barreras que impiden que ese tipo de comercio sea de completo éxito. Por lo tanto, el objetivo general de este trabajo fue analizar el efecto del régimen aduanero especial de drawback como reductor de costos en el sector de fruticultura. La metodología utilizada se basó en investigación de campo, descriptiva y cualitativa, el instrumento de investigación fue caracterizado por una entrevista con itinerario preestablecido, dirigido a una empresa de fruticultura irrigada en la ciudad de Mossoró / RN. A través del análisis de los datos, se verificó 
que existe una diversidad de incentivos fiscales y regímenes aduaneros que abarcan a empresas que favorecen aún más la competitividad del empresariado en el mercado externo. Se percibió también que sin los incentivos fiscales y sin el drawback la importación de insumos serían prácticamente inviables, debido a la alta carga tributaria brasileña.

Palabras clave: Comercio exterior; Las importaciones; Inconveniente.

\section{INTRODUÇÃO}

o cenário econômico, as empresas procuram cada vez mais maximizar
resultados e ampliar sua participação no mercado através da importação de
recursos para suprir a carência de sua produção, além da busca por efetivas reduções nos custos e nas cargas tributárias. Sendo assim, o comércio de produtos do mercado exterior se torna cada dia mais constante, mas somente faz-se possível devido à chegada das mercadorias em seu destino com valor compatível às demais, em tempo hábil, e com alta qualidade (SILVANO; PETRI, 2005).

Diante desse desafio, o Brasil, que de acordo com uma pesquisa divulgada em 2016 pelo Fórum Econômico Mundial (FEM) está entre os 10 países com a maior carga tributária do mundo, demonstrando possuir uma alta carga tributária, vem a cada dia tentando desenvolver formas que favoreçam, agreguem valor e reduzam o custo do produto nacional. Com isso, foi desenvolvido um incentivo fiscal chamado de Drawback, que é considerado um dos mais antigos à exportação, tendo seu início na Inglaterra por volta do século XIV, este é definido como o "reembolso de impostos", nele a empresa adquire os produtos no mercado interno e externo, se comprometendo a exportar um produto final.

Um estudo feito por Vieira (2005) consta que em virtude do porte da empresa, que movimenta milhões todos os anos com importações de insumos, a alternativa de redução de custos tributários através do drawback é totalmente viável para o negócio da organização, apesar de que muitas companhias desconheçam a utilização desse regime.

Segundo Castro (2001), o regime aduaneiro Drawback contribui na redução dos custos de fabricação dos produtos exportados, uma vez que os valores das alíquotas de importação e o da mercadoria adquirida no exterior quando agregados representam um valor altíssimo no custo total do produto exportado.

Diante disso, a pesquisa pretende resolver a seguinte problemática: Qual o efeito do Regime Aduaneiro Especial de Drawback como redutor de custos em uma empresa frutícola de melão? O objetivo geral do estudo é o de evidenciar o efeito do regime aduaneiro especial de drawback como redutor de custos em uma empresa frutícola de melão.

Uma pesquisa extraída do site do Ministério da Indústria, Comércio Exterior e Serviços, a Balança Comercial Brasileira registrou que de janeiro a dezembro de 2016, as exportações com drawback atingiram US\$ 36,06 bilhões, o que representa 19,5\% do total exportado no período. No mesmo período, as importações com drawback atingiram US\$ 6,9 bilhões, correspondendo a $5 \%$ do total importado. Além disso, estudos mostram que o regime aduaneiro especial de Drawback é sem dúvida um instrumento eficaz de internacionalização às empresas no mercado externo. Entretanto, para que a empresa disfrute de forma unânime este benefício de desoneração de impostos, é de notória relevância que toda a equipe conheça bem o fluxo, planeje e acompanhe todo o processo.

Dessa forma, o presente estudo se mostra relevante, uma vez que o Drawback se caracteriza por ser um incentivo à exportação, representado por um regime aduaneiro especial, que possibilita a restituição, isenção ou suspensão do recolhimento dos impostos e taxas incidentes sobre insumos importados ou adquiridos no mercado interno, que serão utilizados na industrialização dos produtos à serem exportados. Segundo Vieira (2005), o incentivo em 
questão causa um estímulo às exportações, pois tem como objetivo proporcionar redução no custo final das exportações e obter melhores condições de competitividade no mercado internacional. $\quad O$ presente trabalho está estruturado a partir dessa introdução com uma breve apresentação do trabalho e seus objetivos, logo em seguida o referencial teórico que tratará do conceito e aplicações do comércio exterior, assim como as exportações e importações, com destaque para o regime de drawback e suas características, finalizando com a metodologia, os resultados e discussões, as considerações finais e as referências utilizadas na construção do trabalho.

\section{REFERENCIAL TEÓRICO}

\subsection{COMÉRCIO EXTERIOR}

O comercio exterior é a atividade de compra, troca ou venda de mercadorias e produtos e está presente desde o início das civilizações, mas a sua evolução econômica, social e política se tornou crescente nos últimos séculos devido a dispersão das empresas multinacionais e o consequente avanço dos modais de transportes (MEIRA, 2014). Dessa forma, percebe-se que a globalização favoreceu às empresas uma maior e melhor mobilidade de matérias-primas ao redor do mundo(SILVANO; PETRI, 2005).. De acordo com Silva (2017), os métodos de produção que precisaram ser inovados, estabeleceram uma maior flexibilidade nos sistemas de fabricação dos produtos, a fim de atender mercados consumidores de localidades distintas e aproveitar da melhor maneira possível a utilização do espaço, das matérias-primas e da mão de obra, assim como o setor de transportes, que precisou se adaptar às novas demandas para garantir uma distribuição eficiente e segura das mercadorias.

A partir do momento em que a troca de mercadorias passou a ser uma atividade comum entre os países no mundo, o comércio internacional tornou-se de fundamental relevância para suprir quaisquer que sejam as suas necessidades - à abundância ou à falta de recursos, clima ou trabalho (BALLOU, 2006). Na opinião de Segre (2010), a expressão comércio internacional emprega-se na troca de bens e serviços entre nações distintas, resultante das especializações de cada nação a partir da divisão internacional do trabalho. A disponibilidade de recursos, as desigualdades de produção e as vantagens de produzir com menor custo um produto de melhor qualidade levam os países a buscarem o que falta em seu território, disponibilizando assim o que tem com abundância em suas terras (MACIEL; LIMA, 2002)..

Além disso, a melhoria da qualidade de produção pode ser um fator determinante nas relações comerciais, mesmo que uma abertura de fronteiras possa limitar a produção interna por meio da concorrência estrangeira, estimula o crescimento e a qualidade na produção da indústria nacional. A partir do comércio exterior as empresas podem se manter equilibradas e livres de concorrência, sem estar presas a único mercado (KEEDI, 2011).

\subsection{EXPORTAÇÃO}

Entende-se por exportação a saída de um produto para o exterior. É comum associar exportação à venda de mercadoria, porém há a prática de exportar amostras, uma doação ou até mesmo produtos para apresentação em feiras (VIERA, 2005). De acordo com Ratti (2007), exportação é definida pela remessa de bens de um país para outro, mas que não devem ser limitados apenas aos bens e materiais que serão utilizados para industrialização, como também os serviços ligados a essa exportação, já que muitas vezes se faz necessário o uso de agentes de cargas, responsáveis pela contratação do frete seja ele marítimo ou aéreo, e de armadores, àqueles que irão realizar o transporte da carga. 
A estratégia de destinar uma parcela de sua produção para o mercado interno e outra para o mercado externo permite que a empresa amplie sua carteira de clientes, o que significa correr menos riscos, pois, quanto maior o número de mercados ela atingir, menos dependente do mercado interno ela será. Ademais, as exportações poderão dar-se com cobertura cambial, aquelas que possuem forma de pagamento obrigatório, e sem cobertura cambial, quando os importadores não efetuam pagamento pelas mercadorias recebidas, cujo estas geralmente são mercadorias para amostra ou para exposições (MEIRA, 2014).

Vale ressaltar que os produtos que serão direcionados para o mercado externo devem atender a todas as exigências e padrões internacionais no que se refere a: embalagem, qualidade, design, preço, certificação de matérias-primas (certificado de origem), formas de produção, entre outros. Além disso, o Governo tem papel fundamental no sentido de promover e incentivar as exportações por meio de políticas e programas nacionais que colaborem com as empresas, principalmente, no que diz respeito às questões fiscais e tributárias, já que esse tipo de comércio favorece o crescimento da balança comercial (MALUF, 2000).

\subsection{IMPORTAÇÃO}

Importar significa comprar uma mercadoria de um outro país. Diante de um mercado cada vez mais competitivo, é cada vez maior a necessidade das empresas expandirem seus negócios. Umas das alternativas de expansão é a importação de mercadorias, sejam elas insumos, materiais indiretos, mercadorias para consumo, para revenda ou bens para o ativo imobilizado. Segundo Keedi (2012) a importação de mercadorias de vários países poderá eliminar os problemas nacionais. De acordo com Ratti (2007), importação é a entrada de mercadorias no país oriunda do exterior. Porém, para que se concretize um processo de importação, além da entrada de produtos estrangeiros no país é necessário um trâmite legal, realizado de acordo com as normas da legislação aduaneira.

Anterior ao ato de importação, deve-se verificar todos os custos de transporte, armazenagem, seguro, que tipo de documentação é exigida para a nacionalização da mercadoria, se vai ter anuência de algum órgão (Inmetro, Anvisa ou Ministério da Agricultura, Pecuária e Abastecimento), se possui o amparo de acordos internacionais (Mercosul ou ALADI), qual a classificação fiscal da mercadoria (NCM/SH) e etc. (SOUSA, 2011).

Uma vez chegada ao território nacional, a mercadoria proveniente do exterior, deverá ser submetida a um procedimento administrativo específico para regularização dessa entrada, esse procedimento é chamado de despacho aduaneiro de importação (RIBEIRO; 2014). A Guia do Comércio Exterior e Investimento (2012) afirma que perante lei a mercadoria só é considerada importada após sua internalização, mediante a etapa de desembaraço aduaneiro e do recolhimento dos tributos exigidos em lei. Entretanto, há desvantagens no processo de importação: a demora da chegada do produto adquirido no exterior e alta carga tributária. Sousa (2011) sustenta que a importação como qualquer transação comercial, apresenta riscos relacionados a operação, como não receber a mercadoria conforme as especificações de compra, atraso, avarias e variação cambial (já que se trata de uma compra internacional). Esses riscos podem variar por diversas situações que venham a ocorrer durante o percurso da mercadoria do país de origem até o destino final, ou até mesmo diante os imprevistos ocorridos com greves dos trabalhadores portuários, de fiscais da Receita Federal, funcionários de aeroportos, divergências documentais, dentre outros.

Como já foi dito anteriormente, nota-se que é de suma relevância o incentivo do governo através de sistemas e procedimentos, utilizando-se de mecanismos e instrumentos de apoio que aumentem a sua participação no comércio exterior. O principal órgão envolvido no comércio exterior brasileiro, responsável pelas políticas e ações assim como regulamentação e execução de programas relacionados ao comércio exterior brasileiro é o Ministério de Desenvolvimento, 
Indústria e Comércio Exterior (MDIC). As esferas governamentais, como o MDIC, contribuem com o aumento nos índices de importação de bens e mercadorias, criando benefícios fiscais e incentivos, visando agilizar a chegada da mercadoria ao seu destino final com um menor custo, de forma que o produto alcance o mercado em condições de competir com o preço da concorrência (GARCIA, 2001). Através de incentivos fiscais, pode-se a haver diminuição da carga tributária de produtos industrializados ou matérias-primas provenientes do exterior, como, a redução, isenção ou diferimento dos tributos que será devido à importação dos respectivos produtos importados.

Por meio da importação, as empresas podem aumentar sua capacidade de produção, possibilitar a inovação e também viabilizar o trabalho com novas ou diferentes tecnologias. Podendo assim, oferecer produtos diferenciados aos consumidores cada vez mais exigentes, evoluindo no aspecto competitividade perante seus concorrentes e principalmente, obtendo produtos a custos reduzidos.

\subsubsection{Tributação incidente na importação}

Nas importações incidem o Imposto de Importação (II), o Imposto sobre Produtos Industrializados (IPI), o Imposto sobre Operações relativas à Circulação de Mercadorias e sobre Prestação de Serviços de Transporte Interestadual e Intermunicipal e de Comunicação (ICMS), a Contribuição sobre o Financiamento Social (Cofins) e o Programa de Integração Social (PIS), o Adicional de Frete para Renovação da Marinha Mercante (AFRMM) e taxas como de Utilização do Sistema Integrado de Comércio Exterior (Siscomex).

Conforme Ashikaga (2008, p.23) "numa importação de bens estrangeiros, ocorrerá fato gerador do Imposto de Importação (II), do IPI, do ICMS, além de PIS/Pasep e COFINS Importação, instituídos pela Lei $\mathrm{n}^{\mathrm{o}} 10.865 / 04$ ". As cargas tributárias dos produtos estão definidas a partir de sua Nomenclatura Comum do Mercosul (NCM). Dessa forma cada produto tem sua alíquota de Imposto de Importação, Imposto sobre Produtos Industrializados, PIS/PASEP, COFINS e ICMS.

O Imposto de Importação é de competência da União e incide sobre mercadorias que ingressam no território nacional. O IPI é também de competência da União e incide sobre produtos industrializados nas situações definidas no desembaraço aduaneiro. As contribuições para PIS/Pasep e COFINS incidem sobre a importação de bens e serviços do exterior e são de competência da União, destinadas ao financiamento da Seguridade Social. O ICMS é de competência dos Estados e Distrito Federal e também incide sobre bens importados com a finalidade de dar tratamento isonômico aos produtos nacionais.

O AFRMM é incidente nas operações de descarregamento da embarcação em porto brasileiro, a qual pode ser proveniente do exterior, em navegação de longo curso ou de portos brasileiros, em navegação de cabotagem ou em navegação fluvial e foi instituído pelo Decretolei $\mathrm{n}^{\mathrm{a}}$ 2.404/1987 e disciplinado pela Lei $\mathrm{n}^{\circ}$ 10.893/2004. Este mesmo decreto "destina-se a atender aos encargos da intervenção da União no apoio ao desenvolvimento da marinha mercante e da indústria de construção e reparação naval brasileiras (...)" (RFB, 2017). Já a taxa Siscomex é devida no ato do registro da Declaração de Importação (DI) e de acordo com Castro Junior e Passold (2011) essa taxa é devido à utilização do sistema Siscomex que integra as atividades de registro, acompanhamento e controle das operações de comércio exterior.

\subsubsection{Planejamento tributário nas operações de importação}

O planejamento tributário tem como objetivo a maximização da lucratividade mediante a redução de tributos que se dá após análise prévia da legislação para fins de escolher a forma mais adequada de tributação, para que dessa forma possa-se avaliar se a importação de 
mercadorias é realmente vantajosa. Considerando a opinião Hanlon e Heitzmann (2010) sobre a redução ou diferimento dos tributos, também conhecido pela literatura internacional como corporate tax avoidance, é uma prática aceitável mesmo que não esteja muitas vezes prevista por lei, mas que consequentemente, são ações que resultam em reduções dos tributos da empresa.

No planejamento tributário observa-se a possibilidade de redução de custos nas importações, tendo em vista os tributos sujeitos ao princípio da não-cumulatividade, que garante as empresas brasileiras o crédito dos tributos pagos na compra de determinado produto ou insumo, o que possibilita maior competitividade na revenda, ou na comercialização de produtos

fabricados. Isso faz com que as organizações não fiquem com esse ônus, mas sim o consumidor final. Este princípio pode ser utilizado tanto no mercado interno quanto em mercadorias procedentes de importação (OLIVEIRA et al., 2007).

Diante de um país com um sistema de normas tributárias tão complexas, pode-se perceber a relevância dessa ferramenta, fundamental para aspectos como sobrevivência no mercado e competitividade. Para Romano (2013), é válido importar produtos para o Brasil, sendo aconselhável aos contribuintes uma consulta a um especialista na matéria, para identificar a efetiva tributação de determinado produto que pretenda importar para evitar surpresas desagradáveis quando de sua chegada em solo nacional.

É necessário ressaltar também que a opção do regime tributário - simples, presumido ou lucro real - da empresa deve ser muito bem pensada, pois é ele quem vai determinar quais tributos serão não-cumulativos assim como a forma de apuração do Imposto de Renda e CSLL, como afirma Mota (2012) quando cita que a empresa precisa tomar a decisão de efetuar as importações ainda no início do exercício fiscal, pois a depender do regime de tributação escolhido fará ou não jus ao crédito da Cofins e do PIS, já que somente as empresas optantes pelo lucro real têm direito a esse crédito.

\subsubsection{Redução dos impactos tributários no processo de importação de bens e insumos agrícolas}

A redução dos impactos tributários se torna possível através do uso das lacunas da legislação tributária, ou seja, são formas de reduzir os impactos dos altos valores dos impostos de forma legal, uma vez que tudo está previsto por lei. Quando se fala na aquisição de máquinas e equipamentos, bens de informática e telecomunicação (BIT) assinalados na Tarifa Externa Comum (TEC), a legislação nacional dispõe de um incentivo fiscal na redução do Imposto de Importação (II), uma vez que seja comprovado através de laudo técnico, a não similaridade do produto no Brasil. Trata-se de um incentivo do governo para investimento em ativo produtivo e é referido como Ex-tarifário. Esse regime consiste em três pontos fundamentais conforme o MDIC (2017):

1 - Viabiliza aumento de investimentos em bens de capital (BK) e de informática e telecomunicação (BIT) que não possuam produção equivalente no Brasil;

2 - Possibilita aumento da inovação por parte de empresas de diferentes segmentos da economia, com a incorporação de novas tecnologias inexistentes no Brasil, com reflexos na produtividade e competitividade do setor produtivo - conforme preconizado nas diretrizes do Plano Brasil Maior - PBM;

3 - Produz um efeito multiplicador de emprego e renda sobre segmentos diferenciados da economia nacional.

A Tarifa Externa Comum (TEC) varia de $0 \%$ a $20 \%$. No caso de autopeças, a alíquota do Imposto de Importação é fixada em $2 \%$. A redução do Imposto de Importação depende de habilitação específica no Sistema Integrado de Comércio Exterior (Siscomex). Os critérios para 
a análise técnica dos processos de concessão de Ex-tarifários para Bens de Informática e Telecomunicações (BIT) estão dispostos na Portaria SDP/MDIC nº 92, de 14/05/2015.

A concessão do regime foi estabelecida pela Resolução no 17/2012, da Câmara de Comércio Exterior (Camex), mas está regulamentada pela Resolução Camex nº 66, de 14 de agosto de 2014, que explicita requisitos e procedimentos relacionados ao tema. Esta concessão só ocorre depois do parecer favorável do Comitê de Análise de Ex-tarifários (Caex).

Alguns segmentos como agricultura e máquinas e equipamentos poderão ter suas bases de pagamento de ICMS reduzidas. Na importação de bens que constituirão o ativo imobilizado, poderá se valer da utilização do diferimento de ICMS. O diferimento é uma espécie de substituição tributária, em que existe uma postergação ou adiamento do pagamento do imposto e, ao mesmo tempo, a transferência da responsabilidade para o pagamento do imposto a um terceiro. Para Brugnara (2013), significa adiar a cobrança do imposto e o lançamento deste e a responsabilidade do respectivo recolhimento é transferida para a operação subsequente. Diferimento muitas vezes não é considerado um benefício fiscal, pois não retira as operações do campo de incidência do imposto, apenas transfere para etapa futura da operação da circulação o momento do lançamento tributário.

O ICMS é considerado um tributo não-cumulativo, sendo o valor pago no momento da importação creditado pelo importador para posteriormente ser compensado nas operações futuras que forem sujeitas a esse tributo aborda o ICMS e IPI como um tributo não-cumulativo porque: Por ser um imposto de competência dos Estados e do Distrito Federal, podem existir diferentes incentivos e alíquotas para sua tributação. Cada estado institui o ICMS por alíquota, a qual é regulamentada através de um Decreto (regulamento do ICMS) (SILVA, 2005). As reduções, incentivos, benefícios e isenções nas alíquotas do ICMS são firmadas através de Convênios entre 2 ou mais Estados, observado na Figura 01:

Figura 1 - Alíquotas de ICMS 


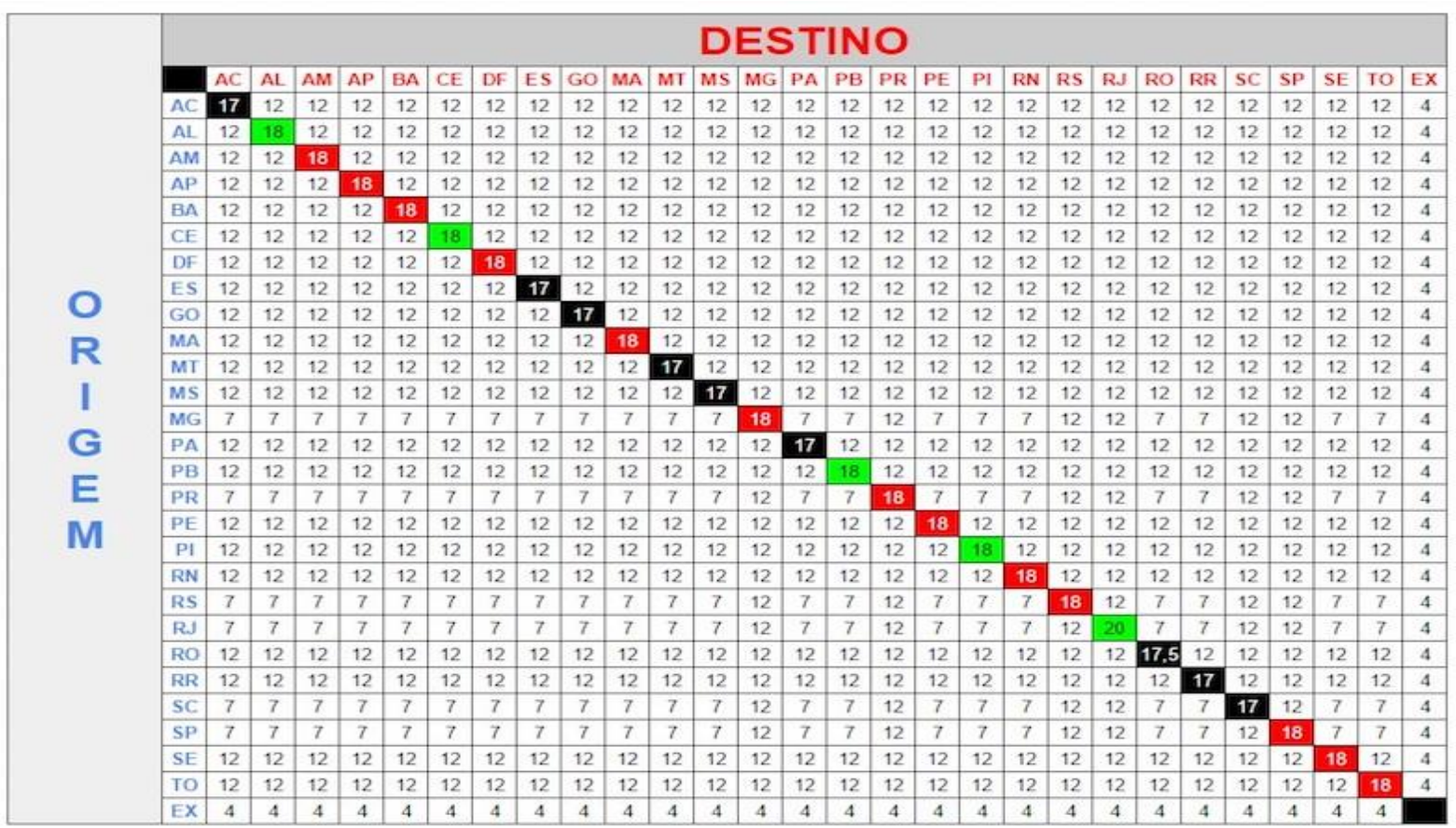

Fonte: Sage Negócios (2017).

No estado no Ceará, o Decreto No 24.569/1997 que consolida e regulamenta a legislação do ICMS do estado, permite o diferimento desse tributo nas importações de ativos, de acordo com o seu artigo $13^{\circ}$ do referido decreto:

$\S 1^{\circ} \mathrm{O}$ disposto neste artigo, aplica-se também na operação de importação de:

I - petróleo cru; (Redação do inciso dada pelo Decreto No 26834 DE 22/11/2002).

II - máquinas, equipamentos e estruturas metálicas de unidades produtivas para compor o ativo permanente de estabelecimento agropecuário, bem como de estabelecimento importador beneficiário do Fundo de Desenvolvimento Industrial (FDI), desde que não esteja inscrito no Cadastro de Inadimplentes da Fazenda Pública Estadual (CADINE). (Redação do inciso dada pelo Decreto $\mathbf{N}^{\circ} 26033 \mathrm{DE}$ 16/10/2000).

III - máquinas, equipamentos, veículos e estruturas metálicas adquiridos do exterior por empresas de arrendamento mercantil para utilização por empresa beneficiária do Fundo de Desenvolvimento Industrial (FDI), não inscrita no Cadastro de Inadimplentes da Fazenda Pública Estadual (CADINE), formalizada mediante contrato de arrendamento mercantil com prazo pré-determinado, contraprestações mensais, com ou sem opção de compra no final do contrato. (Redação do inciso dada pelo Decreto No 28267 DE 05/06/2006).

IV - os produtos referidos no inciso VI do caput, nas mesmas condições nele estabelecidas. (Inciso acrescentado pelo Decreto No 26094 DE 27/12/2000).

$\mathrm{V}$ - matéria-prima e insumos para utilização no processo industrial, adquiridos por estabelecimento importador beneficiário do Fundo de Desenvolvimento Industrial (FDI), não inscrito no Cadastro de Inadimplentes da Fazenda Pública Estadual (Cadine); (Redação do inciso dada pelo Decreto No 26483 DE 26/12/2001).

VI - outros bens necessários à implantação de projeto agroindustrial, adquiridos por estabelecimento agrícola importador, beneficiário do FDI, não inscrito no Cadine; VII - combustíveis líquidos e gasosos derivados de petróleo, gás natural e combustíveis dele derivados, importado por refinaria de petróleo, para a saída subseqüente. (Inciso acrescentado pelo Decreto No 28667 DE 16/03/2007).

Para empresas do ramo agrícola, como esta que serviu para o presente estudo, há o benefício de isenção de ICMS nas importações de alguns tipos de fertilizantes e adubos provenientes do exterior. Vale lembrar que os fertilizantes ou adubos só poderão ser importados 
se estiverem de acordo com as normas exigidas pelo Ministério da Agricultura, Pecuária e Abastecimento (MAPA) e com autorização de embarque através da Liberação de Importação (LI). No estado do Ceará, se onde a empresa possui filial, é regulamentado pelo artigo $6^{\circ}$ do Decreto 24.569/1997 a isenção desses tipos de produtos:

\begin{abstract}
Art. $6^{\circ}$ - Ficam isentas do ICMS, sem prejuízo de outras hipóteses previstas na legislação tributária estadual, as seguintes operações:

LXXXI - interna e de importação de farelo e torta de soja, DL Metionina e seus análogos, amônia, uréia, sulfato de amônio, nitrato de amônio, nitrocálcio, MAP (mono-amônio fosfato), DAP (di-amônio fosfato), cloreto de potássio, adubo simples e composto e fertilizantes (Convênios ICMS n ${ }^{\circ}$ s 36/92, 70/92, 89/92, 144/92, 28/93, 114/93, 29/94, 68/94, 151/94, 22/95, 21/96, 20/97, 48/97, 100/97, 05/99, 10/01 e 58/01 - válida até 30 de abril de 2002).
\end{abstract}

Como já se sabe, é devido nas importações de produtos, bens e serviços, a incidência de PIS/COFINS e a quase todas as importações, a alíquota aplicável do PIS é de $2,1 \%$ e a da Cofins é de $9,65 \%$, podendo o último variar até $14 \%$. Com isso, foi estabelecido pelo governo a redução a zero nas alíquotas de PIS/PASEP e da COFINS, que têm como principal objetivo baixar os preços dos produtos ao consumidor e estimular a produção. A lei $\mathrm{n}^{\circ}$ 10.925/2004 decreta que as alíquotas do PIS/PASEP e da COFINS incidentes na importação e na comercialização do mercado interno de fertilizantes e defensivos agropecuários serão reduzidas a zero:

\footnotetext{
Art. $1^{\circ}$ Ficam reduzidas a 0 (zero) as alíquotas da contribuição para o PIS/PASEP e da Contribuição para o Financiamento da Seguridade Social - COFINS incidentes na importação e sobre a receita bruta de venda no mercado interno de: (Vigência) (Vide Decreto $\mathrm{n}^{\circ} 5.630$, de 2005)

I - adubos ou fertilizantes classificados no Capítulo 31, exceto os produtos de uso veterinário, da Tabela de Incidência do Imposto sobre Produtos Industrializados TIPI, aprovada pelo Decreto $\mathrm{n}^{\circ} 4.542$, de 26 de dezembro de 2002, e suas matériasprimas;

II - defensivos agropecuários classificados na posição 38.08 da TIPI e suas matériasprimas;

III - sementes e mudas destinadas à semeadura e plantio, em conformidade com o disposto na Lei $\mathrm{n}_{-}^{\circ} 10.711$, de 5 de agosto de 2003, e produtos de natureza biológica utilizados em sua produção;

IV - corretivo de solo de origem mineral classificado no Capítulo 25 da TIPI;
}

Diante de toda carga tributária, Maydew (2001) enfatiza que os estudos sobre os impostos na contabilidade precisam ser mais vastos e que deve-se incorporar também a teoria e evidências da economia e financias, já que se faz totalmente necessário um estudo que possibilite a redução legal deste impacto no processo de importação de mercadorias.

\title{
2.3.4 Drawback
}

As necessidades de redução dos diversos custos existentes nas operações de importação de insumos são alvos de estudos minuciosos sobre todas as alternativas que envolvem estas operações, principalmente os efeitos tributários, em função do impacto financeiro, cujo qualquer vantagem na redução dos custos tributários pode representar um diferencial relevante nos processos de importação de mercadorias de maneira geral.

Entre essas alternativas o drawback representa atualmente um dos mais relevantes mecanismos de incentivos à exportação. $O$ objetivo desse regime não consiste somente na desoneração dos tributos, mas também em incentivar o país a inserir-se no mercado 
internacional, proporcionando assim resultados favoráveis para a balança comercial (MOORI, BENEDETTI; KONDA, 2012)

Esse incentivo foi criado por meio do Decreto-Lei $n^{\circ} 37$, de 21 de novembro de 1966, que permite que as empresas exportadoras importem insumos, matérias-primas e partes e peças, destinados à fabricação dos produtos que serão exportados, utilizando-se da suspensão ou isenção dos tributos pagos ou a serem pagos na importação, desde que comprovadas às operações e que tenham elas ocorrido antes ou depois de apresentados as informações necessárias para que seja autorizado o gozo deste benefício, de acordo com a modalidade de drawback ao qual a empresa esteja enquadrada. Segundo a Receita Federal do Brasil (RFB, 2012):

[...] existem três modalidades de drawback: isenção, suspensão e restituição de tributos. A primeira modalidade consiste na isenção dos tributos incidentes na importação de mercadoria, em quantidade e qualidade equivalentes, destinada à reposição de outra importada anteriormente, com pagamento de tributos, e utilizada na industrialização de produto exportado. A segunda, na suspensão dos tributos incidentes na importação de mercadoria a ser utilizada na industrialização de produto que deve ser exportado. A terceira trata da restituição de tributos pagos na importação de insumo importado utilizado em produto exportado.

De acordo com RFB (2012), a modalidade de drawback restituição praticamente não existe mais, restando às empresas realizar seus planejamentos tributários tomando por base as modalidades de isenção e suspensão.

O regime de drawback, no qual Sagaz (2007) sustenta, é um benefício antigo, no entanto, pouco conhecido e utilizado pelas empresas exportadoras, que possibilita às empresas a suspensão ou isenção do Imposto de Importação, IPI, ICMS, do Adicional ao Frete para Renovação da Marinha Mercante (AFRMM), além de outras taxas de serviços incidentes na importação. A diferença entre as modalidades de suspensão e isenção, é que na primeira o pedido de concessão deverá ser feito antes da importação dos insumos destinados à industrialização de produto que será destinado à exportação, para que as importações a serem realizadas já gozem da suspensão dos tributos, já no drawback isenção, o pedido de concessão é feito após a exportação do produto industrializado. Antes de dar início ao uso do regime de drawback, a empresa importadora deve fazer o pedido de ato concessório juntamente ao Ministério do Desenvolvimento, Indústria e Comércio Exterior (MDIC). Vale ressaltar que o prazo de validade do ato é de um ano, podendo ser prorrogado somente uma vez, por igual período (LOPEZ; GAMA, 2008).

Para os casos em que drawback for suspenso deve ser encaminhada a solicitação de suspensão para junto a Secretaria de Comércio Exterior (Secex) e a mesma concede a autorização da suspensão. Nos casos de Drawback Suspensão o AC (Ato Concessório) poderá ser solicitado através do SISCOMEX (Sistema Integrado de Comércio Exterior). Já para as modalidades de Isenção e Restituição deverá ser preenchido um formulário separadamente.

O Secex é o responsável pela análise do pedido, para verificar as informações nele prestadas e constatar o cumprimento dos pré-requisitos necessários, por meio do Relatório Unificado de Drawback (RUD) que deve trazer informações dos Registros de Exportação (RE) e também das Declarações de Importação (DI) registrados no Siscomex, comprovando as operações de exportação e importação. Um dos pré-requisitos é que para utilização do Drawback a empresa só poderá importar até $40 \%$ do valor final do produto, que deverá ser exportado, agregando então o restante do valor do produto no Brasil (ALBUQUERQUE, 2008).

Conforme o art. 73 da portaria que trata sobre o regime em questão, o drawback não poderá ser concedido às empresas quando a importação de mercadoria for utilizada na industrialização de produto destinado ao consumo na Zona Franca de Manaus e em áreas de 
livre comércio localizadas em território nacional, exportação ou importação de mercadoria suspensa ou proibida, exportações conduzidas em moedas não conversíveis (exceto em reais) e importação de petróleo e seus derivados.

Figura 2 - Fluxograma para abertura do Ato Concessório

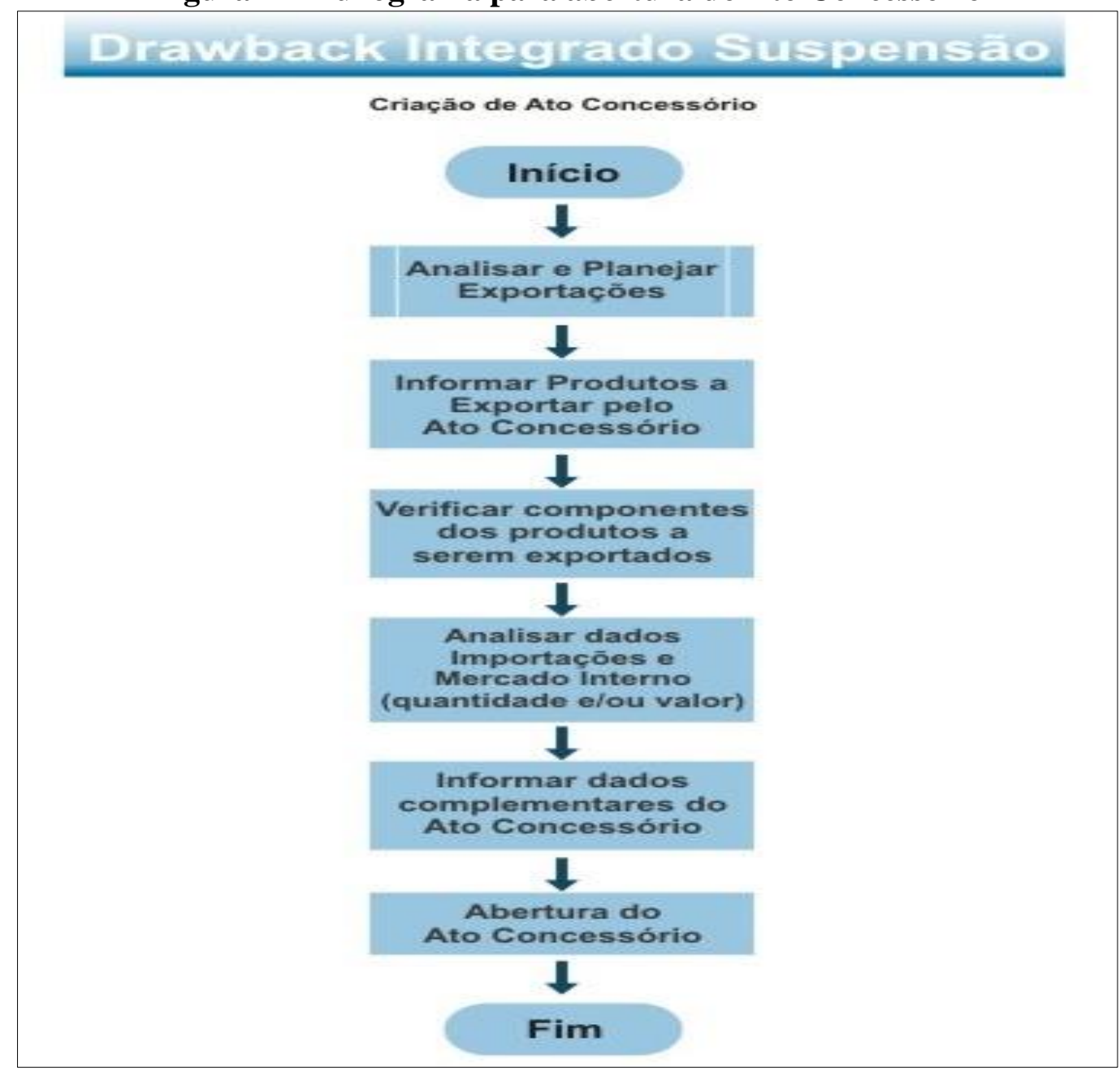

Fonte: Portal Drawback (2017).

Após a abertura do Ato Concessório e deferimento, a empresa assume o compromisso de exportar o produto gerado mediante industrialização da mercadoria adquirida. Caso o importador não cumpra com o compromisso dentro do prazo estipulado, deve-se optar por: devolver o material importado que não foi utilizado para o exterior ou requerer a destruição das mercadorias. A vantagem se caso isso chegue acontecer é que o importador pode requerer junto à Receita Federal a nacionalização dos produtos importados, para que sejam utilizados no mercado interno. Porém, há um maleficio: o pagamento dos tributos referente ao que foi importado. Dessa forma, a empresa deverá recolher os valores relativos a IPI, II, AFRMM e ICMS, somados com juros e multas incidentes em cima desses valores. (Art. 171 da Portaria SECEX no 23, de 14 de julho de 2011).

Além disso, se ocorrer de a empresa não recolher os valores que foram suspensos no ato da importação dentro de 30 dias após o encerramento das exportações será aplicado a multa de $100 \%$ sobre o valor do II e $75 \%$ sobre o valor do IPI (CASTRO, 2001). 


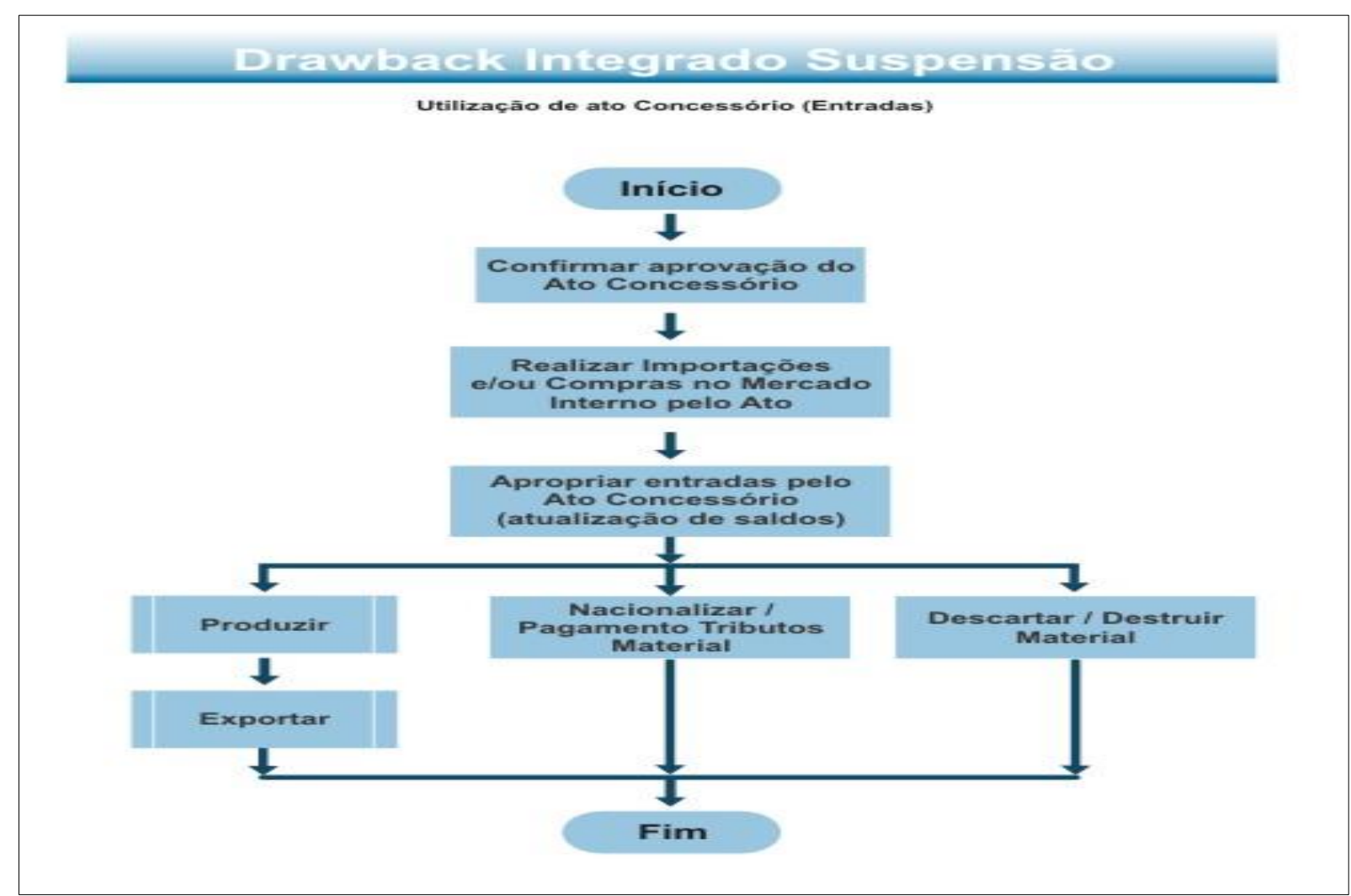

Fonte: Portal Drawback (2017).

Mesmo sendo um incentivo pouco conhecido, o drawback se tornou de grande relevância paras o desenvolvimento da indústria nacional. $\mathrm{O}$ principal fator que leva às empresas a adotarem estratégias internacionais é o retorno que isso pode lhe conceder o que na maioria das vezes reflete-se no aumento considerável da sua carteira de clientes (BARNEY; HESTERLY, 2011). As empresas veem o drawback como um incentivo de proporciona não só o crescimento econômico próprio, mas assim como de todo o país. Estima-se que cerca de 1/5 dos insumos utilizados na fabricação de produtos destinados à exportação se utilizam desse sistema. No ano de 2016, as exportações com drawback atingiram US\$ 42,2 bilhões, representando $22,8 \%$ do total exportado. No mesmo período, as importações com drawback atingiram US\$ 7,2 bilhões, correspondendo a 5,2\% do total importado (MDIC, 2017).

\section{METODOLOGIA}

Quanto aos objetivos o trabalho em questão é classificado como uma pesquisa descritiva, uma vez que, analisa, observa, registra e correlaciona aspectos (variáveis) que envolvem fatos ou fenômenos, sem que o pesquisador interfira neles, neste caso, observa-se o comportamento da empresa do setor de fruticultura, no que tange ao drawback.

Para a realização do presente estudo foi utilizada uma abordagem qualitativa, uma vez que o pesquisador mantém contato direto com o objeto de estudo, mas sem interferir nos resultados adquiridos. Para Flick (2009), esse tipo de abordagem consiste nas reflexões do pesquisador a respeito de sua pesquisa como parte do processo de produção do conhecimento, demonstrando as variações na perspectiva sobre o objeto de estudo.

Salienta-se que a abordagem qualitativa dessa pesquisa considera a utilização de quadros, planilhas e percentuais para apresentação dos resultados, entretanto não será utilizada base estatística. Tal orientação está em linha com Malhotra (2012, p. 130) que indica que na perspectiva qualitativa, "[...] para a exibição dos dados o pesquisador deve desenvolver uma 
interpretação visual por meio de ferramentas como diagramas, gráficos ou matrizes, de forma a auxiliar no processo de esclarecimento dos padrões e as inter-relações".

Em relação aos procedimentos utilizados para coleta de dados, foi realizado por meio de uma entrevista semi-estruturada com 10 (dez) questionamentos, direcionada ao controller, contador e o gestor de importação de uma empresa no ramo de agronegócio na cidade de Mossoró-RN. A entrevista em questão foi gravada sob permissão dos gestores, afim de facilitar o momento, sem perda de tempo para redigir as respostas. Como fonte secundaria, foram utilizados materiais de livros, artigos, trabalhos acadêmicos e os relatórios de importação e exportação da empresa.

A amostra da pesquisa foi caracterizada por uma empresa de fruticultura produtora de melão, localizada na cidade de Mossoró, no estado do Rio Grande do Norte. Esse estado, possui uma representatividade no segmento de fruticultura, sendo responsável por $65 \%$ de exportações agrícolas no ano 2017 (G1, 2017). De acordo com o IBGE (2016) o destaque desse estado está na produção de melão, sendo o maior produtor com uma quantidade 354.793 de unidades de melão, no ano de 2016.

O roteiro da entrevista apresentou quatro blocos para a coleta de dados. O bloco 1 , referiu-se a empresa e ao perfil do respondente e sua participação dentro da entidade. O bloco 2 , referiu-se às principais atividade de comércio exterior dentro da empresa, assim como os produtos que são exportados, os países que geralmente compram às mercadorias e a participação desse mercado no faturamento da instituição. O bloco 3, questiona-se se a empresa utiliza de algum incentivo fiscal e aduaneiro para nas importações de insumos e às assertivas relacionadas à utilização do drawback nas importações, concluindo com as possibilidades que a utilização do drawback trouxe para empresa. O bloco 4, pretende-se descobrir o quão relevante é o desenvolvimento do planejamento tributário dentro da empresa.

\section{RESULTADOS E DISCUSSÕES}

Esta etapa apresenta os resultados obtidos de acordo com os objetivos propostos na introdução através dos relatos dos entrevistados de uma empresa de fruticultura na cidade de Mossoró-RN. Sendo apresentado: caracterização da empresa e dos entrevistados, exportação, regimes tributários de incentivos a importação e planejamento tributário como ferramenta na redução de custos.

\subsection{CARACTERIZAÇÃO DA EMPRESA E DOS ENTREVISTADOS}

Inicialmente, para conhecer melhor a empresa onde o estudo foi aplicado perguntou-se sobre a entidade e o tempo em que a mesma está no ramo da fruticultura irrigada. A empresa é uma companhia de capital nacional fundada em 1995. Em seus 22 anos de indústria, consolidou seu nome no agronegócio através de investimentos em novas tecnologias, pesquisas constantes e compromisso social. Contanto com aproximadamente 9.000 colaborados no período de safra, é hoje responsável pela produção de mais de 30.000 hectares de melões e melancias e a maior exportadora de frutas in natura do Brasil, chegando a exportar mais de 14 milhões de caixas de frutas por ano.

Quanto aos entrevistados, um deles foi o gestor de controller que trabalha a 10 anos na empresa e se mostra de fundamental relevância dentro do seu papel, uma vez que suas atividades vão desde o planejamento do que será plantado em função da necessidade dos clientes, assim como também o planejamento da compra de insumos até o controle de custos e fluxo de caixas.

Os outros entrevistados foram, o contador da empresa, que vêm trabalhando dentro da companhia há 7 anos, porém somente há 3 como gestor do setor de contabilidade buscando 
sempre agregar e evoluir no que diz respeito aos conhecimentos na aérea de forma que possa contribuir ao crescimento da empresa, e o outro o gestor de importação, que está há 9 anos à serviço da empresa gerenciando as importações e participando do controle do Ato Concessório de Drawback.

\subsection{COMÉRCIO EXTERIOR}

Neste tópico, procurou-se explanar sobre as atividades de comércio exterior exercida pela empresa. Na primeira questão, interrogou-se sobre o que a empresa exporta e quais países. Pode-se averiguar então, que o melão e a melancia são os carros-chefes da empresa, sendo estes exportados principalmente para o mercado britânico, holandês, alemão, italiano, português e espanhol. Além desses, são exportados também, mamão e banana, porém numa escala reduzida. As exportações são parte fundamental do faturamento da empresa, chegando a representar significativamente $60 \%$ do faturamento anual. Esse dado foi obtido após perguntar-se sobre o percentual das exportações do faturamento da empresa e se sua participação demonstra ser significativa. Depois de muitos estudos e análises comparativas feitos no decorrer dos séculos, pode-se chegar à conclusão que as estratégias de um comercio para fora, ou melhor, comércio internacional, trouxe ganhos consideráveis no crescimento das industrias (SARQUIS, 2011).

\section{Gráfico 1 - Comparativo de exportações $2015 \times 2016$}

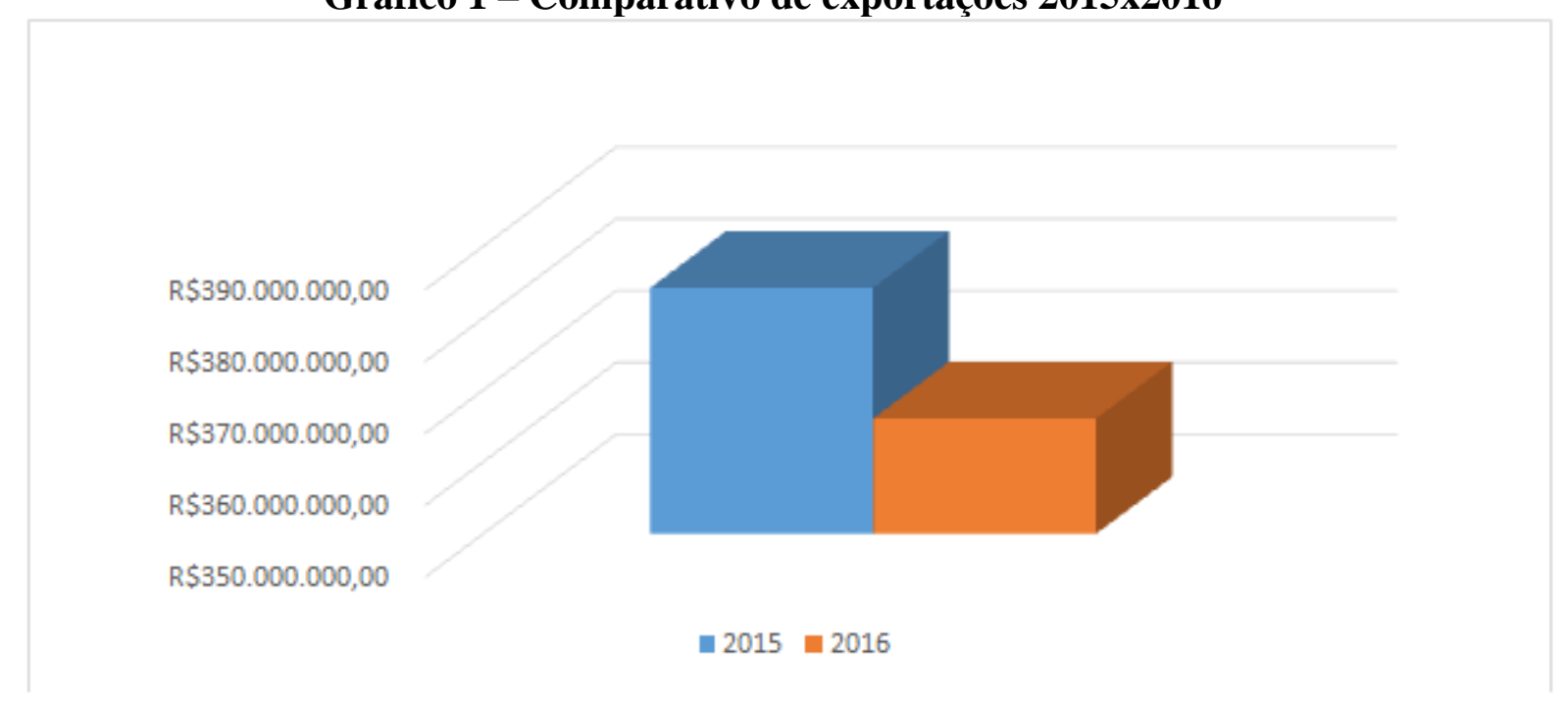

Fonte: Dados da Pesquisa (2018).

Como se pode analisar pelo gráfico e apesar de que no ano de 2016 foram exportadas mais de 152 mil toneladas de fruta, concentrando-se principalmente no mercado europeu, houve uma redução no faturamento anual de exportações comparando ao ano de 2015. Esse efeito deu-se pela baixa no câmbio no ano de 2016 comparado ao ano de 2015. Desse modo, pode-se deduzir que o papel da taxa de câmbio se mostra de grande relevância, já que altera o resultado no âmbito internacional ao impulsionar as mudanças nos preços dos bens nacionais em relação aos estrangeiros, além de ser relevante na determinação da estrutura produtiva da economia (CRUZ, NAKABASHI, SCATOLIN, 2008). Ou seja, com o aumento da taxa de câmbio, as exportações diminuem, uma vez que o consequente aumento no valor do produto torna quase impossível competir com o mercado externo.

\subsection{REGIMES TRIBUTÁRIOS DE INCENTIVOS A IMPORTAÇÃO}


Alguns fatores podem dificultar as atividades de comércio exterior praticadas pela empresa, sendo a principal e mais impactante a alta carga tributária. Para Sagaz e Sagaz (2007) a influência dos tributos nas operações de compras de insumos são significativos, aumentando os custos de produção e os custos financeiros, e consequentemente dificulta o processo de formação dos preços de vendas. Dessa forma, é de relevante conhecimento que os gestores responsáveis, tenham a ciência da legislação para que dessa forma, possa utilizar ferramentas que o governo possui para ajudar a quebrar essas barreiras e reduzir consideravelmente os altos custos de importação.

Tendo isso em mente, foi questionado aos entrevistados se a empresa utiliza algum regime aduaneiro especial ou afins nas atividades de importação de insumos. Foi dito que, para aqueles produtos que não há similar nacional, como máquinas, há importação com a redução de alguns impostos, como Imposto de Importação e IPI, ou a utilização do drawback na importação de insumos, que suspende os impostos de II, IPI, PIS, COFINS e ICMS, além da redução dos custos de importação como o AFRMM (Adicional ao Frete para Renovação da Marinha Mercante). Foi citado também, que alguns insumos utilizados na agricultura há a redução de PIS e COFINS e a isenção de ICMS, de acordo com a legislação especifica. Bizelli (2006) diz que estes regimes são considerados regimes aduaneiros, pois trazem benefícios nas operações de importação e exportação, como a suspensão de tributos federais, estaduais e municipais, conforme cada legislação. Dentro disso, tem-se resposta quando questionado se os benefícios fiscais brasileiros contribuem na redução dos custos tributários de importação.

Posteriormente, replicou-se que os insumos importados via drawback, são àqueles que serão utilizados na produção ou que são ligados diretamente ao produto final que será exportado - melão e melancia -, como caixas de papelão para o acondicionamento dos frutos, sacos plásticos e fertilizantes. A suspensão dos impostos incidentes na importação dos insumos é o fator mais relevante e positivo desse regime. Garcia (2001) afirma que com a eliminação dos impostos, existe uma probabilidade maior do produto ser exportado e assim conseguir atingir o mercado externo e competir com a concorrência.

Gráfico 2 - Importação de Caixas sem Drawback

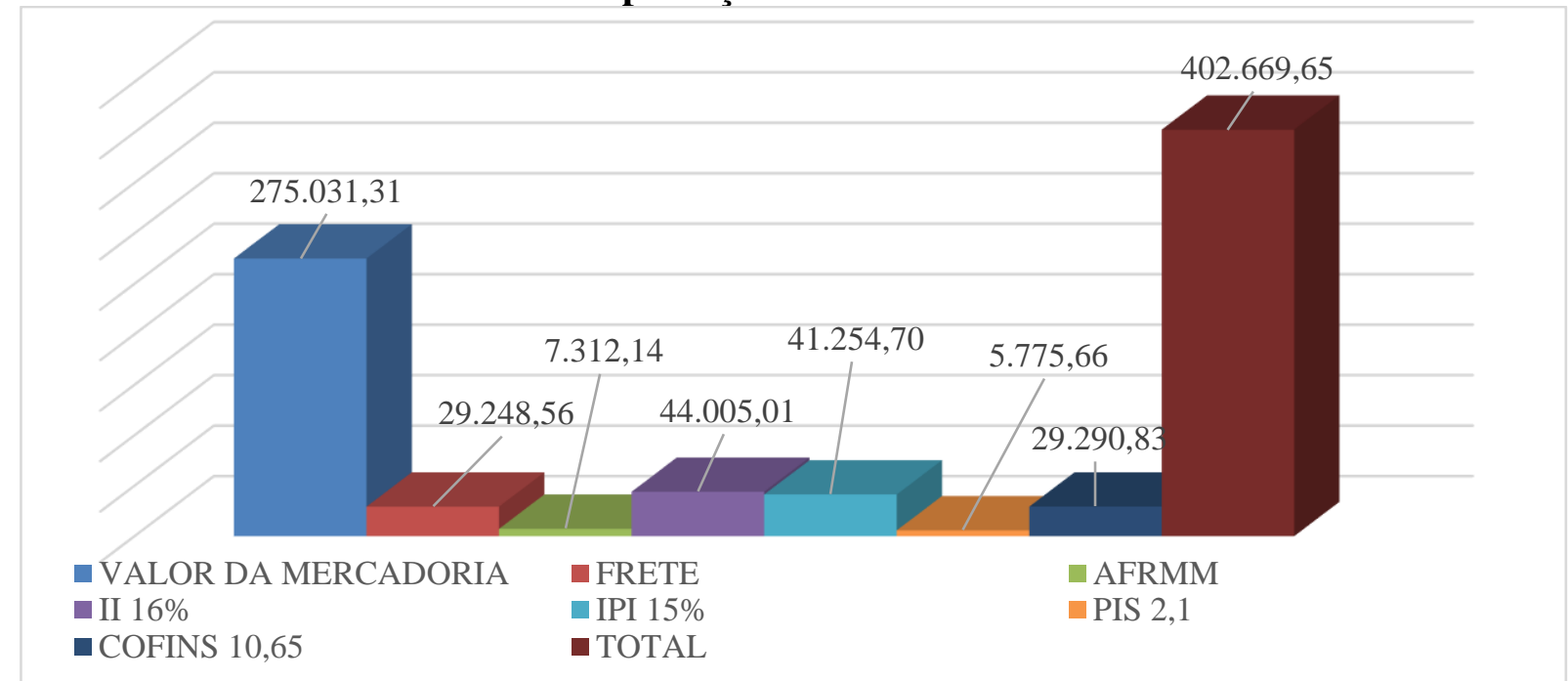

Fonte: Dados da Pesquisa (2018).

Pode-se analisar pelo gráfico 2, com valores em reais, a importação de uma quantidade $\mathrm{X}$ de caixas e o recolhimento de cada imposto incidente nessa compra. Uma vez que o valor do frete já está incluso ao valor do produto, chega-se a pagar pela mercadoria aproximadamente $130.000,00$ reais à mais do seu valor. 


\section{Gráfico 3 - Importação de Caixas com Drawback}

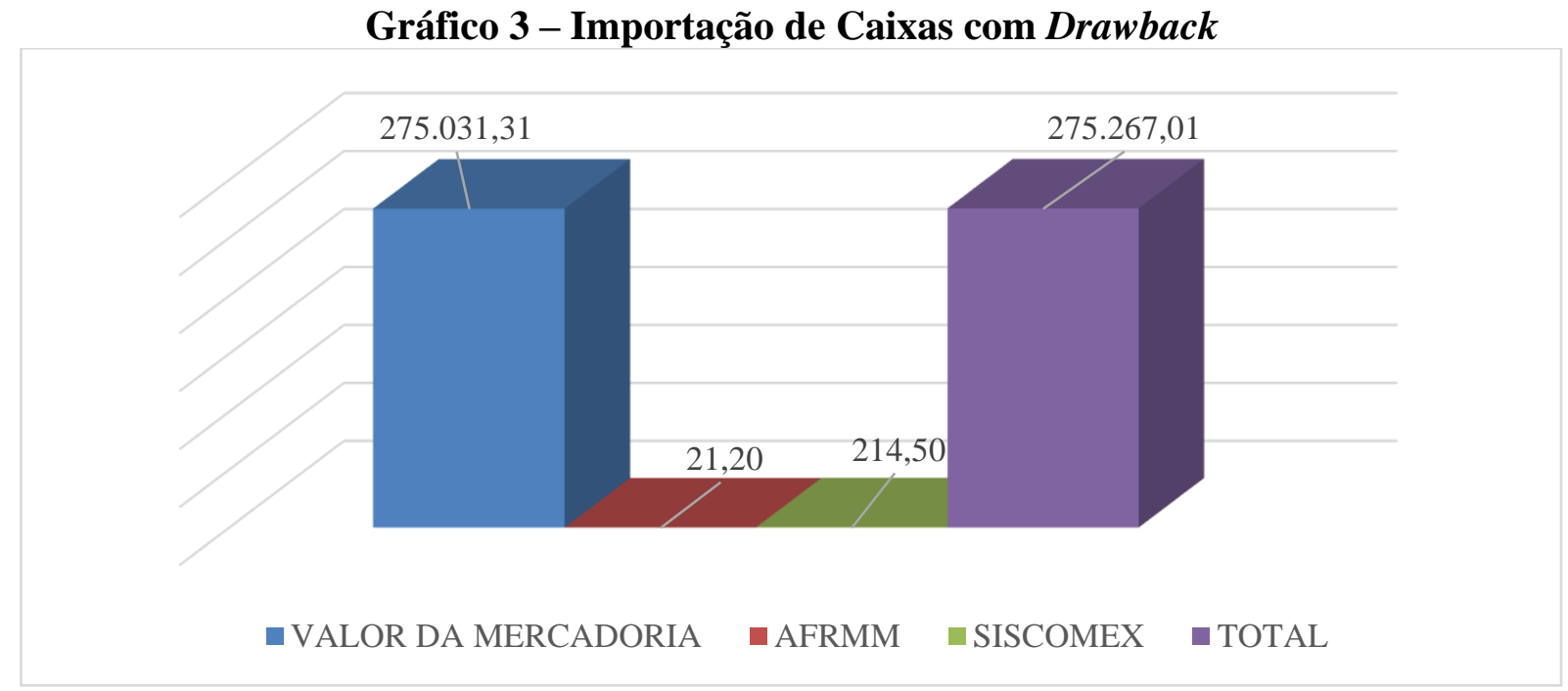

Fonte: Dados da Pesquisa (2018).

Já no gráfico 3, tem-se a importação da mesma quantidade $X$ de caixas, com valores já em reais, utilizando-se do drawback, onde houve a suspensão de todos os impostos, apenas o pagamento da Taxa Siscomex e 21,20 reais de AFRMM. Citando esses dados, conclui-se a relevância do incentivo em questão e o fato de não recolher os tributos ICMS, IPI, PIS, COFINS e a redução do AFRMM representou uma redução da carga tributária e consequentemente a redução nos custos com as importações.

Mesmo possuindo fábricas nacionais que produzem caixas para embalagens dos frutos com uma qualidade tão boa quanto a do mercado exterior, o preço no material importado se mostra bem mais competitivo, além de claro, ter o benefício de importar com a suspensão dos impostos através do drawback. Esse argumento deu-se a perguntar se o drawback possibilita a importação de matéria prima importada de melhor qualidade e menor custo em relação ao nacional. Porém, ao mesmo tempo, a moeda é um fator que interfere, uma vez que o câmbio estiver alto, fica inviável a compra no mercado exterior. Ainda assim, a baixa nesses custos de importação possibilita à empresa ter um preço de venda satisfatório no mercado exterior, adquirindo matéria-prima e embalagens de boa qualidade e com o preço inferior ao que é praticado no mercado doméstico. Como diz Kotler (2005), a globalização e a tecnologia foram os motivadores para que as empresas pudessem concorrer com o mercado externo e trazer produtos para dentro do seu país por preços menores do que o mercado nacional.

Para encerrar o tópico, foi interrogado aos entrevistados se o regime de Drawback possibilitou o aumento das exportações e fez assim a empresa se tornar de grande renome na área do agronegócio. Notou-se então que sem o incentivo havia uma certa dificuldade às exportações dos frutos, principalmente quando se fala em competir com o mercado externo, mas a falta de uma maior competitividade nacional também fez com que a empresa crescesse e se tornasse o que ela é hoje, além de claro, o investimento na qualidade do produto.

\subsection{PLANEJAMENTO TRIBUTÁRIO COMO FERRAMENTA NA REDUÇÃO DE CUSTOS}

Nas aquisições de insumos o custo representa a soma de todos os valores agregados ao bem, incluindo frete, seguro e os impostos. Dessa forma, o planejamento tributário tem como intuito a maximização da lucratividade e a competitividade do empreendimento, mediante 
economia de tributos que se dá após análise da legislação vigente, comparando os prováveis resultados, para fins de escolher a forma mais adequada de tributação (MOTA, 2012).

O controller e o contador, juntamente com o responsável pelas importações da empresa, podem coordenar de forma eficaz o processo de gestão tributária com ênfase no planejamento tributário, apresentando alternativas legais que reduzem a carga tributária e otimizam o fluxo de caixa com a redução dos custos de produção e importação. Com isso, foi questionado a sobre a relevância do planejamento tributário dentro da empresa. A conclusão é de que o planejamento, o delineamento e a programação dos tributos como um todo, não só nas importações, se mostra de grande relevância, uma vez que o mesmo contribui na redução da carga tributária, propiciando a empresa possuir preços competitivos no mercado internacional. A partir do planejamento, é possível identificar como os tributos impactarão na empresa, no fluxo de caixa e na rentabilidade final de seus produtos, possibilitando à companhia tomar decisões estratégicas antecipadas a fim de otimizá-los.

\section{CONSIDERAÇÕES FINAIS}

As operações de comércio exterior proporcionam que diversos países possam interagir economicamente. Para ser sustentável neste mercado globalizado e competitivo é necessário que a empresa esteja capacitada para competir da melhor forma possível contra as barreiras tributárias brasileiras. Neste sentido, o incentivo à exportação e a redução das cargas tributárias são mecanismos relevantes para que a empresa usufrua das vantagens do processo de globalização.

O presente estudo pretendeu evidenciar o efeito do regime aduaneiro especial de drawback como redutor de custos em uma empresa frutícola de melão, a partir de uma pesquisa aplicada através de entrevista aos gestores de importação, controladoria e contabilidade, sendo o mesmo atingido, pois o regime em questão é de suma relevância e impacta positivamente nas operações da empresa, trazendo reduções significantes nos custos de importação. Os gestores de contabilidade, controladoria e importação a partir da visão sistêmica e o conhecimento das operações, são os responsáveis e coordenadores, que identificam e orientam na utilização dos incentivos fiscais presentes na legislação tributária nacional.

A avaliação do regime de drawback com base em suas modalidades, é positiva, tendo em vista que sem esse incentivo às importações teriam um custo bem maior para empresa, tornando praticamente inviável a importação da matéria-prima pela alta carga tributária incidente nas importações. Porém, averiguou-se que o drawback não é o único incentivo que contribui na importação de insumos no país. No ramo agrícola, que é o caso da empresa em questão, há incentivos que reduzem a alíquota de PIS e Cofins a zero e isenção do ICMS para matérias-primas, e redução no imposto de importação para máquinas que não possuem similar nacional.

No que tange a relevância do planejamento tributário no auxílio às importações para empresa, conclui-se como positiva, uma vez que é essencial que haja conhecimento e compreensão clara destes incentivos e como devem ser utilizados, pois por desconhecimento dessas informações, muitas organizações podem acabar não usufruindo de boas oportunidades na redução de custos com impostos.

Como limitações, pode-se destacar que as respostas obtidas na entrevista se mostraram sucintas, sem maiores aprofundamentos sobre o tema. Ainda assim, conclui-se que os incentivos utilizados contribuem de forma notável no faturamento anual da empresa. Outro fato que merece destaque é o fato da pesquisa ter sido realizado em apenas uma empresa do setor de fruticultura, fato este, que não se podem generalizar ser resultados.

Entretanto, por ser um regime bastante utilizado pelas empresas exportadoras, fica como sugestão para futuros trabalhos a aplicação da pesquisa em um número maior de empresas, para 
que possa servir como fonte de informação para pesquisadores da área e para que se tenha uma maior noção não só do impacto desses incentivos à empresa, mas também as principais limitações e dificuldades na utilização destes incentivos. Por meio desta nova análise, poderá ser traçado um outro plano estratégico, com o objetivo de melhor usufruir dos incentivos fiscais, financeiros e regimes aduaneiros, e assim torná-los de fácil acesso pelos empresários brasileiros.

\section{REFERÊNCIAS}

ALBUQUERQUE, V. Política de comércio exterior: epicentros e epifenômenos do desempenho exportador das empresas brasileiras. Tese (Doutorado em Administração). Rio de Janeiro. Fundação Getulio Vargas, 2008.

ASHIKAGA, C. E. G. Análise da Tributação: na Importação e na Exportação. $4^{a}$ ed. São Paulo: Aduaneiras, 2008.

BARNEY, J. B.; HESTERLY, W. S. Administração estratégica e vantagem competitiva. 3. ed. São Paulo: Pearson, 2011.

BALLOU, Ronald $\mathrm{H}$. The evolution and future of logistics and supply chain management. Produção, v.16, n.3, p.375, Set/Dez 2006.

BIZELLI, J. dos S. Importação: Sistemática administrativa, Cambial e Fiscal. São Paulo: Aduaneiras, 2006.

BRUGNARA, M. Utilização do diferimento como estratégia de planejamento tributário de ICMS de Minas Gerais. Disponível em: <http://blog.brugnara.com.br/2013/08/utilizacaodo-diferimento-como-estrategia-de-planejamento-tributario-de-icms-de-minas-gerais/> Acesso em: 18 de Abril de 2017.

CASTRO, J. A. Exportação - Aspectos Práticos e Operacionais. $8^{\text {a }}$ Edição. São Paulo: Aduaneiras, 2001.

CASTRO JUNIOR, O. A.; PASOLD, C. L. (Orgs.). Direito Portuário, regulação e desenvolvimento. $2^{\mathrm{a}}$ ed. Belo Horizonte: Fórum, 2011.

DECRETO No 5.630 de 22 de Dezembro de 2005. Redução a zero das alíquotas da Contribuição para o PIS/PASEP e da COFINS incidentes na importação e na comercialização no mercado interno de adubos, fertilizantes, defensivos agropecuários e outros produtos. Disponível em: < http://www.planalto.gov.br/ccivil_03/_ato20042006/2005/decreto/d5630.htm> Acesso em: 20 de Abril de 2017.

DECRETO N 24.569 de 31/07/1997. Legislação do Imposto Sobre Operações relativas à circulação de mercadorias e sobre prestações de serviços de transporte interestadual e intermunicipal e de comunicação (ICMS) do Estado do Ceará. Disponível em: <http://www.legiscenter.com.br/minha_conta/bj_plus/direito_tributario/atos_legais_estaduais/ ceara/decretos/1997/d creto_24569_de_04-08-97.htm> Acesso em: 20 de Abril de 2017.

FLICK, U. Introdução à pesquisa qualitativa. $3^{\text {a }}$ edição. Porto Alegre: Artmed, 2009. 
GARCIA, L. M. Exportar: rotinas e procedimentos, incentivos e formação de preços.7 ed. São Paulo: Aduaneiras, 2001. 217 p.

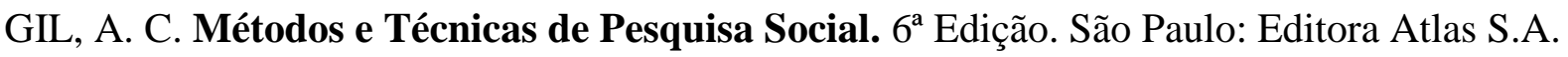
2008.

GUIA DE COMÉRCIO EXTERIOR E INVESTIMENTO - INVEST \& EXPORT BRASIL. Conheça o Drawback. Disponível em: <http://www.investexportbrasil.gov.br/conheca-odrawback> Acesso em: 28 de Abril de 2017.

G1. Mais de $95 \%$ do melão exportado pelo Brasil é produzido no RN.

$<$ https://g1.globo.com/ rn/rio-grande-do-norte/noticia/mais-de-96-do-melao-exportado-pelobrasil-e-produzido-no-rn.ghtml>. Acesso em: 07 de jul de 2018.

HANLON, M; HEITZMAN, S. "A Review of Tax Research.” Journal of Accounting and Economics 50, no. 2-3 (December 2010)

INSTITUTO BRASILEIRO DE GEOGRAFIA E ESTATÍSTICA (IBGE). Quantidade produzida de melão (produção agrícola - lavoura temporária). Disponível em: < https://cidades.ibge.gov.br/brasil/rn/pesquisa/14/10193?tipo=ranking\&indicador=10347>. Acesso em: 19 jul. 2018.

KEEDI, S. ABC do Comércio Exterior. $4^{\text {a }}$ Ed. São Paulo: Aduaneiras, 2012.

KOTLER, P. O marketing sem segredos: trad. Bazan Tecnologia e Lingüística. - Porto Alegre: Bookman, 2005.

LAKATOS, E. M.; MARCONI, M. de A. Metodologia do Trabalho Científico. 2.ed. São Paulo: Atlas, 1991.

LOPEZ, J. M. C.; GAMA, M.. Comércio Exterior Competitivo. $4^{\mathrm{a}}$ ed. São Paulo: Aduaneiras, 2008.

MACIEL, G. M.; LIMA, L. M. M. Consórcios de exportação. São Paulo: Aduaneiras, 2002

MALHOTRA, N. K. Pesquisa de marketing: uma orientação aplicada. 6. Ed. Porto Alegre: Bookman, p. 130, 2012.

MALUF, S. N. Administrando o Comércio Exterior do Brasil. São Paulo: Aduaneiras, 2000.

MAYDEW, E. Empirical tax research in accounting: A discussion. Journal of Accounting and Economics, 2001.

MEIRA, L. A. Regimes Aduaneiros Especiais. São Paulo: Revistas dos Tribunais, Ministério do desenvolvimento, indústria e comércio exterior. Definição de SISCOMEX, 2010

Disponível em: < portalmdic/siscomex/siscomex.htm>. acesso em 09/12/2018. 


\section{MINISTÉRIO DO DESENVOLVIMENTO, INDÚSTRIA E COMÉRCIO EXTERIOR} (MDIC). Disponível em: <http://www.mdic.gov.br/index.php/comercioexterior?view=default $>$ Acesso em: 3 de Abril de 2017.

MOORI, R. G.; BENEDETTI, M. H.; KONDA, S. T. O regime aduaneiro de Drawback em operações logísticas internacionais. Revista Pretexto, v. 13, n. 1, p. 114-133, 2012.

MOTA, A. S. da. Planejamento tributário nas operações de importação. Artigo científico (Pós-Graduação Stricto Sensu em Ciência Jurídica) - Curso de Mestrado em Ciência Jurídica da Universidade do Vale do Itajaí (Univali). Santa Catarina, 2012.

NAKABASHI, L; CRUZ, M. J. V. da; SCATOLIN, Fábio Dória. EFEITOS DO CÂMBIO E JUROS SOBRE AS EXPORTAÇÕES DA INDÚSTRIA BRASILEIRA. Revista de Economia Contemporânea. Rio de Janeiro. v. 12, n. 3, p. 433-461, set./dez. 2008.

RATTI, B. Comércio Internacional e Câmbio. 10ª ed. São Paulo: Aduaneiras. 2007.

RIBEIRO, et al. Utilização dos incentivos fiscais e financeiros para exportação como estratégia de competitividade, Universidade Federal de Uberlandia. Disponível em: <http://www.pablo.prof.ufu.br/artigos/cbc2.pdf> Acesso 09/01/2019.

ROMANO, F. F. QUAIS IMPOSTOS UMA PEQUENA EMPRESA DEVE PAGAR? Revista Exame. São Paulo. 30 de Julho de 2013. Disponível em:

<http://exame.abril.com.br/pme/os-impostos-que-sua-empresa-deve-pagar-na-importacao/> Acesso em: 24 de março de 2017.

SAGAZ, F. R; SAGAZ, C. A.. A participação da controladoria na gestão estratégica da tributação reduzindo os custos das importações. In: XIV Congresso Brasileiro de Custos João Pessoa - PB - Brasil. De 05 de dezembro a 07 de dezembro de 2007.

SAGE NEGÓCIOS. Tabela ICMS atualizada com as alíquotas dos Estados. Disponível em: <http://blog.sage.com.br/tabela-icms-2017-atualizada/> Acesso em: 2 de maio de 2017.

SEGREE, G. Manual Prático de Comércio Exterior. Thadeu. $3^{\text {a }}$ ed. São Paulo: Atlas 2010.

SEVERINO, A. J. Metodologia do trabalho científico. 22. ed. rev. ampl. São Paulo: Cortez, 2002.

SILVA, J. C. L. da. O Processo de Globalização. Brasil Escola. Disponível em: $<$ http://brasilescola.uol.com.br/geografia/processos-globa.htm>. Acesso em: $18 \mathrm{de}$ abril de 2017.

SILVA, L. L. da. Contabilidade geral e tributária. $2^{a}$ ed. São Paulo: IOB Thomson, 2005.

SILVANO, R. V.; PETRI, S. M. Drawback - compreensão do regime e seus benefícios. Anais do $9^{\circ}$ Congresso Ibernoamericano de Contabilidad e Gestión, Santa Catarina/RS, 2015 . 
SOUSA, M. Importação: a alternativa para competitividade. 2011. Disponível em: $<$ http://www.administradores.com.br/artigos/negocios/importacao-a-alternativa-para-acompetitividade/56576/> Acesso em: 10 de abril de 2017.

VIEIRA, A. Teoria e prática cambial: exportação e importação. $2^{a}$ ed. São Paulo: Lex Editora, 2005. 